\section{Antimicrobial Photothermal Treatment of Pseudomonas Aeruginosa by a Carbon Nanoparticles-Polypyrrole Nanocomposite}

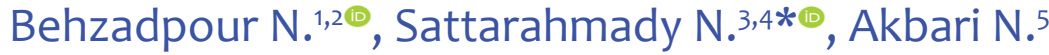

\begin{abstract}
Background: Nowadays, it is needed to explore new routes to treat infectious bacterial pathogens due to prevalence of antibiotic-resistant bacteria. Antimicrobial photothermal therapy (PTT), as a new strategy, eradicates pathogenic bacteria.

Objective: In this study, the antimicrobial effects of a carbon nanoparticles-polypyrrole nanocomposite (C-PPy) upon laser irradiation were investigated to destroy the pathogenic gram-negative Pseudomonas aeruginosa.

Material and Methods: In this experimental study, the bacterial cells were incubated with 50, 100 and $250 \mu \mathrm{g} \mathrm{mL}^{-1}$ concentrations of C-PPy and irradiated with a 808 -nm laser at two power densities of 0.5 and $1.0 \mathrm{~W} \mathrm{~cm}^{-2}$. CFU numbers were counted for the irradiated cells, and compared to an untreated sample (kept in dark). To explore the antibacterial properties and mechanism(s) of C-PPy, temperature increment, reactive oxygen species formation, and protein and DNA leakages were evaluated. Field emission scanning electron microscopy was also employed to investigate morphological changes in the bacterial cell structures.

Results: The results showed that following C-PPy attachment to the bacteria surface, irradiation of near-infrared light resulted in a significant decrement in the bacterial cell viability due to photothermal lysis. Slightly increase in protein leakage and significantly increase intracellular reactive oxygen species (ROS) were observed in the bacteria upon treating with C-PPy.
\end{abstract}

Conclusion: Photo-ablation strategy is a new minimally invasive and inexpensive method without overdose risk manner for combat with bacteria.

Citation: Behzadpour N, Sattarahmady N, Akbari N. Antimicrobial Photothermal Treatment of Pseudomonas Aeruginosa by a Carbon Nanoparticles-Polypyrrole Nanocomposite. J Biomed Phys Eng. 2019;9(6):661-672. https://doi.org/10.31661/jbpe.v0i0.1024.

Keywords

Pseudomonas aeruginosa; Polypyrrole; Nanocomposites

\section{Introduction}

$\Omega$ he prevalence of antibiotic resistance is a growing worldwide problem in controlling pathogens particularly antibiotic-resistant gram-negative bacteria. These bacteria have an additional outer membrane making an impermeable barrier toward antibiotics or drugs in terms of their penetration [1]. Pseudomonas aeruginosa (PA) as an opportunistic gram-negative pathogen infects humans with immunocompromised natural defense, and causes diverse types of infections in urinary tract, respiratory system, bone and joint, soft tissue,
${ }^{1} \mathrm{MSc}$, Department of Medical Physics, School of Medicine, Shiraz University of Medical Sci-

ences, Shiraz, Iran

${ }^{2} \mathrm{MSc}$, Nanomedicine and Nanobiology Research Center, Shiraz University of Medical Sciences, Shiraz, Iran

${ }^{3} \mathrm{PhD}$, Department of Medical Physics, School of Medicine, Shiraz University of Medical Sciences, Shiraz, Iran

${ }^{4} \mathrm{PhD}$, Nanomedicine and Nanobiology Research Center, Shiraz University of Medical Sciences, Shiraz, Iran ${ }^{5} \mathrm{PhD}$, Department of Microbiology, Faculty of Science, Arak Branch, Islamic Azad University, Arak, Iran

*Corresponding author: N. Sattarahmady

Department of Medical Physics, School of Medicine, Shiraz University of Medical Sciences,

Shiraz, Iran

E-mail: nsattar@sums. ac.ir

Received: 24 September 2018 Accepted: 30 October 2018 
bloodstream, and burn injuries [2]. This microorganism exhibits a multidrug resistance to antibiotics, either intrinsically orbecause of acquiring the resistance genes from other bacteria through plasmids [3]. Furthermore, during some infections such as cystic fibrosis, PA forms biofilm by expressing polysaccharidebased extracellular polymeric substance on the surface of bacteria that contributes to high antibiotic resistance $[4,5]$. Therefore, new antimicrobial approaches that target pathogenic bacteria with the global antibiotic-resistant problem should be innovated as alternatives to antibiotics.

There have been attentions on photothermal therapy (PTT) using nanomaterials which are activated by absorption of specific wavelengths of near infrared (NIR) light in a range of 700-1100 nm with sufficient long tissue penetration depth. PTT mechanisms are based on generation of heat leading to irreversible destruction of bacterial cells. This is a noninvasive approach that can improve the therapeutic efficacy and minimize the undesirable side effects of antimicrobial agents [6]. Unlike antibiotics, this approach has been shown no resistance induction in bacteria and can affect antibiotic-resistant bacteria [1]. In addition, PTT kills the bacterial cells more rapidly, compared to traditional antibiotics, and therefore, it has a potential advantage to cease fast spreading infections, e.g. in burn injuries [7].

Nanomaterials are developed due to exhibition of novel characteristics arising from their size-dependent features, and widely used in medical diagnoses and therapies [8-10]. These materials have a usage in biological and medical applications such as labeling of biomolecules [11], drug and gene delivery [12-14], rapid and sensitive microbial detections $[15,16]$, antimicrobial materials [10, 17-19], detection and recognition of DNA and proteins [2022], probing of intrinsic DNA structure [23], biologic substitutes and regenerative medicine [24], hyperthermia [25], separation of specific cell types [26] and MRI contrast agents
[27]. Photothermal agents employed in PTT should absorb NIR light, while they possess photostability with no cytotoxicity. Nanosized photothermal agents include metallic nanomaterials such as gold and silver nanostructures [28], carbon-based nanoparticles such as carbon nanoparticles [29], and single and multiwalled carbon nanotubes [30], quantum dots [31], and conducting polymer nanoparticles [32]. However, low photostability, irreproducible preparation method, accumulation in the body and non-biodegradable features limit application of nanomaterials such as goldbased nanostructures in PTT [28]. Among the nanomaterials, carbon-based and conducting polymers-based nanoparticles are of the most promising types of nanomaterials with a great attention in biomedical applications. Carbon nanostructures possess unique properties such as supreme electrical and thermal conductivity, great photoluminescent properties and high mechanical strength [33]. Moreover, their biocompatibility increases and toxicity decreased by functionalizing which helps them to be more beneficial in medical fields [34]. Recent studies have shown that carbon nanomaterials led to a significant cease in the bacterial growth [29] and the effect was accelerated by laser irradiation [29, 35]. On the other hand, conducting polymers such as polypyrrole (PPy) have been widely used as a contrast agent in optical coherence tomography due to strong absorbance of NIR light [36]. In a study, this utility has been utilized in treatment of cancer by intratumoral injection of PPy that caused a tumor ablation with no considerable side effects [37]. Combination of the characteristics of these two materials as carbon-PPY mixtures, composites or complex structures can possibly elevate their biocompatibility, stability, NIR light absorbance and/ or PPT efficacy.

In this study, the effect of a carbon core-PPY shell nanostructure (C-PPy) in the course of PPT upon a NIR laser irradiation was investigated. Different concentrations of C-PPy at 
two power densities of laser irradiation affected the viability of the pathogenic gram-negative bacterium PA for the first time. PTT of C-PPy was explicated by evaluation of protein and nucleic acid leakage, ROS production, and morphology changes in the bacterial cells.

\section{Material and Methods}

\section{Materials}

In this experimental study, all chemicals were prepared from Sigma (USA), Scharlau (Spain) or Merck (Germany) without further purification. Deionized water (DW) was used throughout the study.

\section{Synthesize and characterization of C-PPy}

Carbon dots (C-dots) were firstly synthesized via a solution synthesis route. Briefly, 5.04 gr citric acid dissolved in $10 \mathrm{~mL}$ water was added into $1.0 \mathrm{~mL}$ ethylenediamine. The mixture was shacked until a clear solution was obtained, and then, the solution was warmed at $200{ }^{\circ} \mathrm{C}$ for 30 min until a dark brown syrup was obtained. After cooling the mixture naturally, the syrup was dialyzed by a $1 \mathrm{KDa}$ membrane versus water for $24 \mathrm{~h}$. A C-dots solution was obtained. Separately, $4 \mathrm{mmol} \mathrm{L}^{-1}$ pyrrole (Py) in $4 \mathrm{~mL} 1.0 \mathrm{~mol} \mathrm{~L}^{-1} \mathrm{HCl}$ was mixed for $30 \mathrm{~min}$ at room temperature. Then $4.0 \mathrm{~mL} \mathrm{C}$ dots solution was mixed with the $\mathrm{Py}-\mathrm{HCl}$ solution and next, $200 \mu \mathrm{L} \mathrm{H}_{2} \mathrm{O}_{2} 29 \%$ was added. The mixture was continuously stirred until the reaction mixture gradually changed from brownish to black. The color change was due to the polymerization of Py in the presence of C-dots. The reaction was allowed to continue for $12 \mathrm{~h}$ to complete polymerization. It was filtered and washed with water and methanol several times. Finally, the filtrate was collected and dried at $50{ }^{\circ} \mathrm{C}$ for $12 \mathrm{~h}$. PPy nanoparticles were synthesized similarly unless $\mathrm{C}$-dots were not added to the reaction mixture.

A TESCAN Mira 3-XMU field emission scanning electron microscope (Czech Repub- lic) was employed to study the particle size and morphology of C-PPy.

CHN elemental analysis was done to determine the carbon content of C-PPy by an ECS 4010 elemental analyzer (Costech, Italy).

\section{Bacteria culture}

All glassware and samples were firstly sterilized in an autoclave at $120{ }^{\circ} \mathrm{C}$ for $20 \mathrm{~min}$. A wild type PA standard strain (PTCC 1430) was received from Iranian Organization of Science and Technology. Bacteria were cultured in brain heart infusion (BHI) broth (Scharlau, Spain) and then incubated at $37^{\circ} \mathrm{C}$ for $24 \mathrm{~h}$. Aliquots of 25-30 mL were transferred to sterile tubes containing $10 \mathrm{~mL}$ of tryptone soy agar (Scharlau, Spain) and incubated for $2 \mathrm{~h}$ at $37^{\circ} \mathrm{C}$ to attain the middle logarithmic phase of growth (600-nm optical density, $\mathrm{OD}_{600}=0.1$, $\left.10^{6}-10^{7} \mathrm{CFU} \mathrm{mL}^{-1}\right)$. Optical density was measured by a microplate spectrophotometer (Epoch, USA) to estimate concentration of bacteria in the medium and employed. Subsequently, $100 \mu \mathrm{L}$ of the bacteria stock was dispersed in vials and reached $250 \mu \mathrm{L}$ with serum for following experiments.

Photothermal effect of C-PPy under laser irradiation

An 808-nm 1.0 W continuous wave laser diode was purchased from Thorlabs (USA) as the light source and C-PPy solution was employed as the photosensitizer to assess the temperature augmentation during photothermal therapy. $250 \mu \mathrm{L}$-solutions of different concentrations of C-PPy $(0,50,100$ and 250 $\left.\mu \mathrm{g} \mathrm{mL}^{-1}\right)$ in the presence of bacterial suspensions $\left(\mathrm{OD}_{600}=0.1\right)$ in vials were separately irradiated by the laser light with power densities of 0.5 and $1.0 \mathrm{~W} \mathrm{~cm}^{-2}$ for different times. Temperature augmentations were recorded at $0,5,10,15$ and $20 \mathrm{~min}$ of light irradiation by a Lutron thermometer (Taiwan) at a precision of 0.01 degree. For a comparison, temperature augmentations of a bacterial suspension (as a control) and the suspensions contain- 
ing PPy nanoparticles, C-dots or C-PPy were recorded at a concentration of $250 \mu \mathrm{g} \mathrm{mL}-1$ upon laser irradiation for $20 \mathrm{~min}$ at a power density of $1.0 \mathrm{~W} \mathrm{~cm}^{-2}$. The probe was placed vertically in the center of the samples, approximately 3-5 mm deep inside the vials. Each experiment was repeated three times in similar conditions.

Photothermal treatment and antibacterial activity of C-PPy

The efficacy of antimicrobial photothermal treatment on the viability of bacterial cells was investigated at C-PPy of different concentrations. Separate groups of the PA were designed as: i) no laser and no C-PPy ([L-N-]); ii), laser irradiation without C-PPy $\left(\left[\mathrm{L}^{+} \mathrm{N}^{-}\right]\right)$; iii), no laser irradiation with C-PPy $\left(\left[\mathrm{L}^{-} \mathrm{N}^{+}\right]\right)$; and iv), exposure to laser with C-PPy $\left(\left[\mathrm{L}^{+} \mathrm{N}^{+}\right]\right)$. The [ $\left.\mathrm{L}^{-} \mathrm{N}^{-}\right]$group was considered as a control. For $\left[\mathrm{N}^{+}\right]$groups, C-PPy solutions at different concentrations of 50,100 and $250 \mu \mathrm{g} \mathrm{mL}^{-1}$ and DW was added to bacterial suspensions $\left(\mathrm{OD}_{600}=0.1\right)$ and mixed by a vortex for $15 \mathrm{~min}$. In $\left[\mathrm{L}^{+}\right]$groups, bacterial suspensions were immediately irradiated by 808 -nm laser light for $20 \mathrm{~min}$ at power densities of 0.5 or $1.0 \mathrm{~W}$ $\mathrm{cm}^{-2}$. For [L-] groups, bacterial suspensions were stored in dark for $20 \mathrm{~min}$.

After irradiation, the samples were prepared in a serial dilution manner with phosphate buffer solution (100 mmol L-1, $\mathrm{pH} 7.0$, PBS), and spread on tryptic soy agar. Following incubation of the samples at $37^{\circ} \mathrm{C}$ for $24 \mathrm{~h}$, the number of CFU formed on the plates was counted and multiplied by the factor of dilution to measure the bacterial viabilities. The experiment was repeated 3 times in similar conditions. Digital images from the culture plates were taken with a digital camera.

\section{Detection of reactive oxygen spe- cies (ROS)}

Intracellular ROS production was detected by 2,7-dichlorodihydro fluorescein diacetate (DCFH-DA) as an oxidant-sensing fluorescent probe. Bacterial samples were centrifuged at $10000 \mathrm{rpm}$ for $20 \mathrm{~min}$, washed 2 times with PBS, mixed with $0.1 \mathrm{mmol} \mathrm{L}^{-1} \mathrm{DCFH}-\mathrm{DA}$ dissolved in a PBS:ethanol mixture $(80: 20, \mathrm{~V} / \mathrm{V})$, incubated in dark at $37{ }^{\circ} \mathrm{C}$ for $30 \mathrm{~min}$, and centrifuged again at $10000 \mathrm{rpm}$ for $20 \mathrm{~min}$. Then, the bacterial suspensions were washed with PBS and re-suspended in PBS by sonication for $10 \mathrm{~min}$. After these, $100 \mu \mathrm{L}$ of the cell extracts was added into $1.0 \mathrm{~mL}$ PBS, and the samples fluorescence intensity was obtained upon excitation at $480 \mathrm{~nm}$ at room temperature by a Cary Eclipse spectrofluorescence (USA).

\section{Evaluation of protein release}

Nanoparticles adhesion to the cell membrane and wall leads to release and leakage of the content of intracellular bacteria [38]. Bradford reagent is used to detect the leaked protein in the released intracellular content [39]. Treated bacteria samples were passed through $0.4-\mu \mathrm{m}$ membranes to eliminate the bacterial cells, and the resultant fluids were incubated with Bradford reagent for $3 \mathrm{~min}$ in dark. After that, absorbance values at $595 \mathrm{~nm}$ were recorded. As a control, a filtered fluid of the bacterial cells with no treatment was selected, and the amounts of the leaked proteins were compared to this control.

\section{Field emission scanning electron microscopy (FESEM) from the bac- teria}

Samples of the control and treated bacteria of $\left[\mathrm{L}^{-} \mathrm{N}^{-}\right]$and $\left[\mathrm{L}^{+} \mathrm{N}^{+}\right]$groups were evaluated by FESEM. To prepare the samples, the bacterial samples were washed with PBS and fixed with $2 \%$ glutaraldehyde dissolved in PBS at $4{ }^{\circ} \mathrm{C}$ for $12 \mathrm{~h}$. After re-washing, the samples were stained by $1 \%$ osmium tetroxide solution during $1 \mathrm{~h}$ at room temperature. After that, the samples were dried in a gradient of acetone and a very thin gold film was coated by sputtering. FESEM was done by a TESCAN Mira 3-XMU field emission scanning electron microscope (Czech Republic). 


\section{Results}

Figure 1A shows FESEM images of C-PPy. The C-PPy images displayed that the nanocomposite comprised near-spherical particles
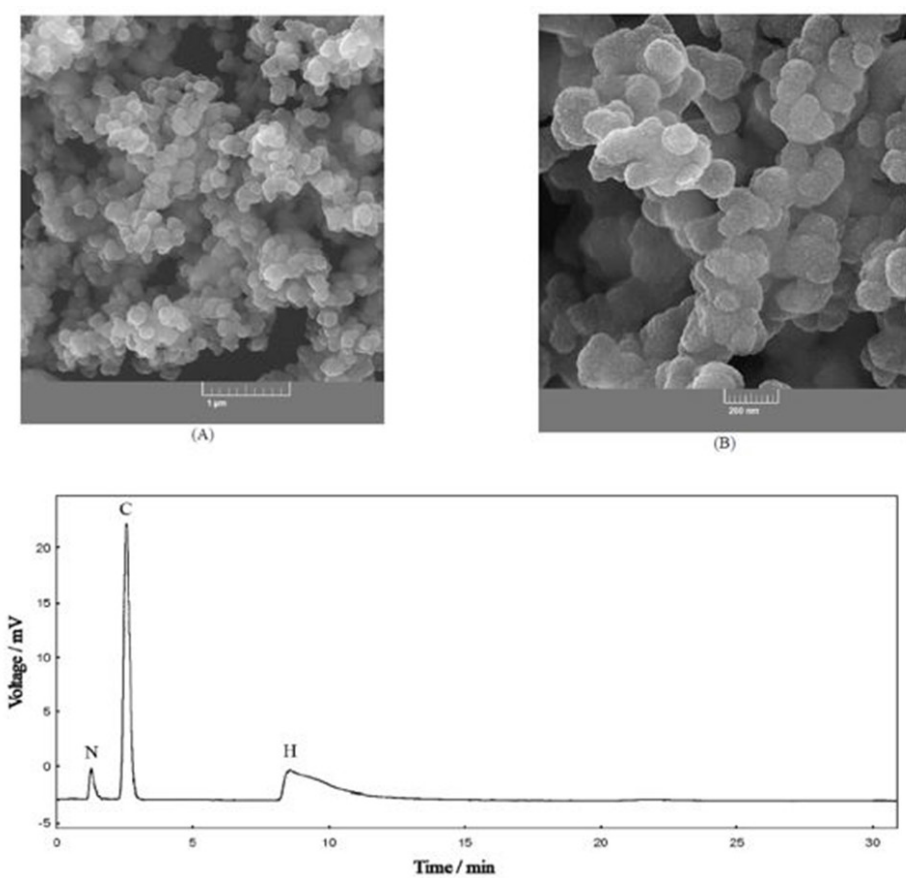

(c)

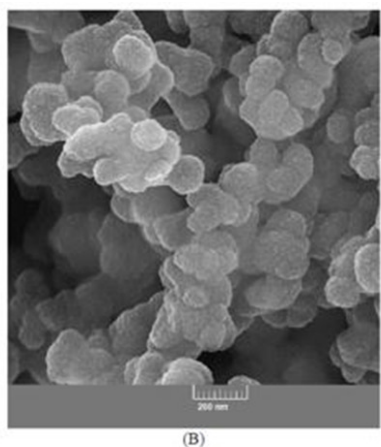

with a mean diameter of $\sim 1.3 \mu \mathrm{m}$.

The results of elemental analysis of C-PPy as a gas chromatogram of its heat combustion are presented in Figure 1B. These results showed

Figure 1: FESEM images of C-PPy (A). A gas chromatogram of C-PPy heat combustion (B).

that the percent of the $\mathrm{C}, \mathrm{H}$ and $\mathrm{N}$ elements in C-PPy were 78.9, 11.4 and 9.7\%, respectively. This indicated that C-PPy comprised 59.8 and $40.2 \%$ from carbon and PPy, respectively.

Figures $2 \mathrm{~A}$ and $2 \mathrm{~B}$ show temperature augmentation in the $\left[\mathrm{L}^{+} \mathrm{N}^{+}\right]$group containing $\mathrm{C}$ PPy solutions of different concentrations of 50, 100 and $250 \mu \mathrm{g} \mathrm{mL}^{-1}$ upon laser irradiation at different times of 5, 10, 15 and $20 \mathrm{~min}$ with two power densities of 0.5 (A) and 1.0 (B) $\mathrm{W} \mathrm{cm} \mathrm{cm}^{-2}$. At both of the power densities, temperature increment was compared with the $\left[\mathrm{L}^{-} \mathrm{N}^{-}\right]$group. The results showed that temperature increment depends on the C-PPy concentration, laser power density or time of irradiation. These results indicated that C-PPy exhibited suitable photothermal efficiency upon NIR laser irradiation. As shown in Fig- ures $2 \mathrm{~A}$ and $2 \mathrm{~B}$, temperature increments upon irradiation at power density of 0.5 and $1.0 \mathrm{~W}$ $\mathrm{cm}^{-2}$ for $20 \mathrm{~min}$ were 10 and $20^{\circ} \mathrm{C}$, respectively. Because the bacterial meiosis usually occurs at $>20 \mathrm{~min}$, the longer times of irradiation more than this time was omitted. Figure $2 \mathrm{C}$ shows temperature augmentations of a bacterial suspension (control) and the suspensions containing PPy nanoparticles, C-dots or C-PPy at a concentration of $250 \mu \mathrm{g} \mathrm{mL}^{-1}$ upon laser irradiation for $20 \mathrm{~min}$ at a power density of $1.0 \mathrm{~W} \mathrm{~cm}^{-2}$.

Figure 2D and 2E represents survival rate of bacteria for each group of $\left[\mathrm{L}^{+} \mathrm{N}^{-}\right],\left[\mathrm{L}^{-} \mathrm{N}^{+}\right]$and $\left[\mathrm{L}^{+} \mathrm{N}^{+}\right]$at different C-PPy concentrations of 50, 100 and $250 \mu \mathrm{g} \mathrm{mL}^{-1}$ and laser light irradiation of power densities of 0.5 (D) and 1.0 (E) $\mathrm{W} \mathrm{cm}$. The percentage of the viable PA 

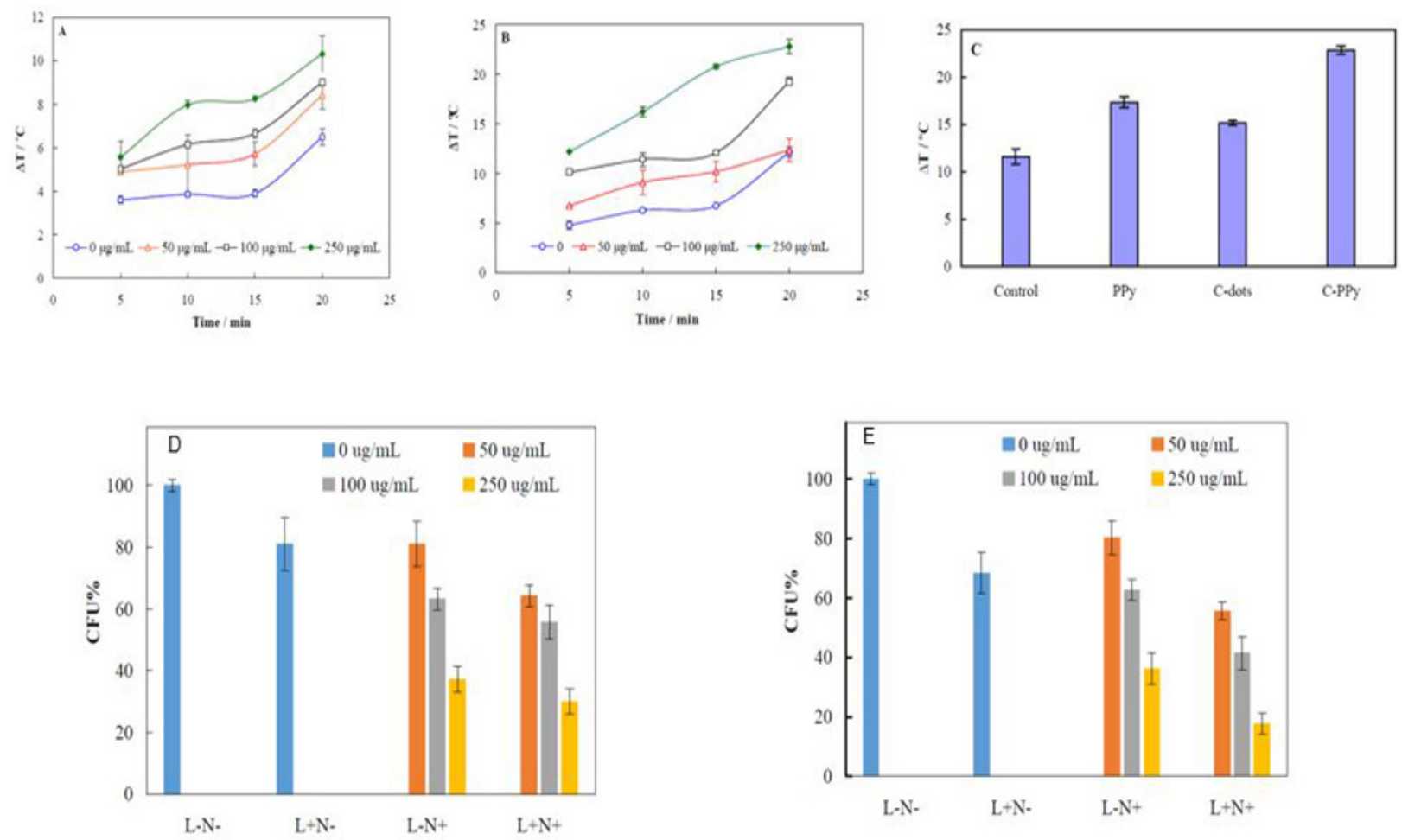

Figure 2: Temperature augmentation in the $\left[\mathrm{L}^{+} \mathrm{N}^{+}\right]$group containing C-PPy solutions of 50, 100 and $250 \mu \mathrm{g} \mathrm{mL}^{-1}$ upon laser irradiation at different times of 5, 10, 15 and 20 min and two power densities of 0.5 (A) and 1.0 (B) $\mathrm{W} \mathrm{cm}^{-2}$. Temperature augmentations of a bacterial suspension (control) and the suspensions containing PPy nanoparticles, C-dots or C-PPy at a concentration of $250 \mathrm{mg} \mathrm{mL}^{-1}$ upon laser irradiation for $20 \mathrm{~min}$ at a power density of $1.0 \mathrm{~W} \mathrm{~cm}^{-2}$ (C). Survival rate of bacteria for $\left[\mathrm{L}^{+} \mathrm{N}\right],\left[\mathrm{L}^{-} \mathrm{N}^{+}\right]$and $\left[\mathrm{L}^{+} \mathrm{N}^{+}\right]$groups at different C-PPy concentrations of 50, 100 and $250 \mu \mathrm{g} \mathrm{mL}-1$ and laser light irradiation of power densities of 0.5 (D) and 1.0 (E) W cm$~^{-2}$.

cells (based on CFU), compared to the viable cells in the $\left[\mathrm{L}^{-} \mathrm{N}^{-}\right]$group (assuming a $100 \%$ viability) were measured. The survival rates of the $\left[\mathrm{L}^{-} \mathrm{N}^{-}\right]$group were 19 and $32 \%$ higher than $\left[\mathrm{L}^{+} \mathrm{N}^{-}\right]$one at the power densities of 0.5 and $1.0 \mathrm{~W} \mathrm{~cm}^{-2}$, respectively. This indicates that the bacterial strains were exclusively affected by laser irradiation. On the other hand, the survival rates of the [ $\left.\mathrm{L}^{-} \mathrm{N}^{-}\right]$group were 19, 37 and $63 \%$ higher than $\left[\mathrm{L}^{-} \mathrm{N}^{+}\right]$one at the C-PPy concentrations of 50, 100 and $250 \mu \mathrm{g} \mathrm{mL}^{-1}$, respectively. This indicates that bacterial strains were exclusively affected by C-PPy. Therefore, the bacterial viability rates in groups showed a decrement in both laser power and C-PPy concentration dependencies. Moreover, the bactericidal rates of the $\left[\mathrm{L}^{+} \mathrm{N}^{+}\right]$group at the laser power density of $0.5 \mathrm{~W} \mathrm{~cm}^{-2}$ were 36,44 and $70 \%$ at C-PPy concentrations of 50, 100 and $250 \mu \mathrm{g} \mathrm{mL}^{-1}$, respectively. The bactericidal rates of the $\left[\mathrm{L}^{+} \mathrm{N}^{+}\right]$group at the laser power density of $1.0 \mathrm{~W} \mathrm{~cm}^{-2}$ were 44,58 and $82 \%$, at C-PPy concentrations of 50, 100 and $250 \mu \mathrm{g} \mathrm{mL}^{-1}$, respectively.

Nanoparticles can represent bactericidal activity through the mechanisms of enzyme inactivation, membrane damage and/or ROS production [40]. To clarify the mechanism(s) of PTT effect of C-PPy, protein and DNA leakage, ROS production and the surface morphology changes in the treated PA with C-PPy under laser irradiation were investigated. Based on the obtained results, $250 \mu \mathrm{g} \mathrm{mL}^{-1}$ of C-PPy and laser power density of $1.0 \mathrm{~W} \mathrm{~cm}^{-2}$ were 
selected for this purpose and in further studies due to the highest bactericidal effect.

Figure 3 shows the absorption intensities of intracellular media of $\left[\mathrm{L}^{-} \mathrm{N}^{-}\right],\left[\mathrm{L}^{+} \mathrm{N}^{-}\right],\left[\mathrm{L}^{-} \mathrm{N}^{+}\right]$and $\left[\mathrm{L}^{+} \mathrm{N}^{+}\right]$groups at different wavelengths and fluorescence spectra of $\left[\mathrm{L}^{-} \mathrm{N}^{-}\right],\left[\mathrm{L}^{+} \mathrm{N}^{-}\right],\left[\mathrm{L}^{-} \mathrm{N}^{+}\right]$and


$\mathrm{W} \mathrm{cm} \mathrm{cm}^{-2}$ laser irradiation after interaction with DCFH. The absorption of intracellular content of bacterial samples at $595 \mathrm{~nm}$ were measured using the Bradford reagent (Figure 3A), at 280 $\mathrm{nm}$ as a sign of protein absorption (Figure $3 \mathrm{~B}$ ) and at $260 \mathrm{~nm}$ related to nucleic acid absorption (Figure 3C). The values of absorbance of $\left[\mathrm{L}^{+} \mathrm{N}^{+}\right]$group at 595 and $280 \mathrm{~nm}$ (Figures 3A and 5B) slightly increased, compared to absorbance values of other groups. The results indicated that a small amount of protein leakage


occurred from the bacteria in $\left[\mathrm{L}^{+} \mathrm{N}^{+}\right]$group. On the other hand, no DNA leakage into the bacterial medium was observed for the $[\mathrm{L}-\mathrm{N}+]$ and $\left[\mathrm{L}^{+} \mathrm{N}^{+}\right]$groups, compared to the $\left[\mathrm{L}^{-} \mathrm{N}^{-}\right]$and $\left[\mathrm{L}^{+} \mathrm{N}^{-}\right]$ones.

The high reactivity of ROS is due to presence of a single unpaired electron, and can cause outstanding damage to the cell structure. Excessive ROS production leads to cell death [41]. Enhancement in fluorescence intensity of DCFH-DA is a sign of intracellular ROS formation. Esterases in cells convert DCFH-DA to the non-fluorescent compound 2,7-dichlorodihydrofluorescein $(\mathrm{DCFH})$. Interaction of ROS with DCFH generates a fluorescent compound dichlorofluorescein (DCF) within the cells [38]. Figure (3D) displays fluorescence spectra of $\left[\mathrm{L}^{-} \mathrm{N}^{-}\right],\left[\mathrm{L}^{+} \mathrm{N}^{-}\right],\left[\mathrm{L}^{-} \mathrm{N}^{+}\right]$and $\left[\mathrm{L}^{+} \mathrm{N}^{+}\right]$
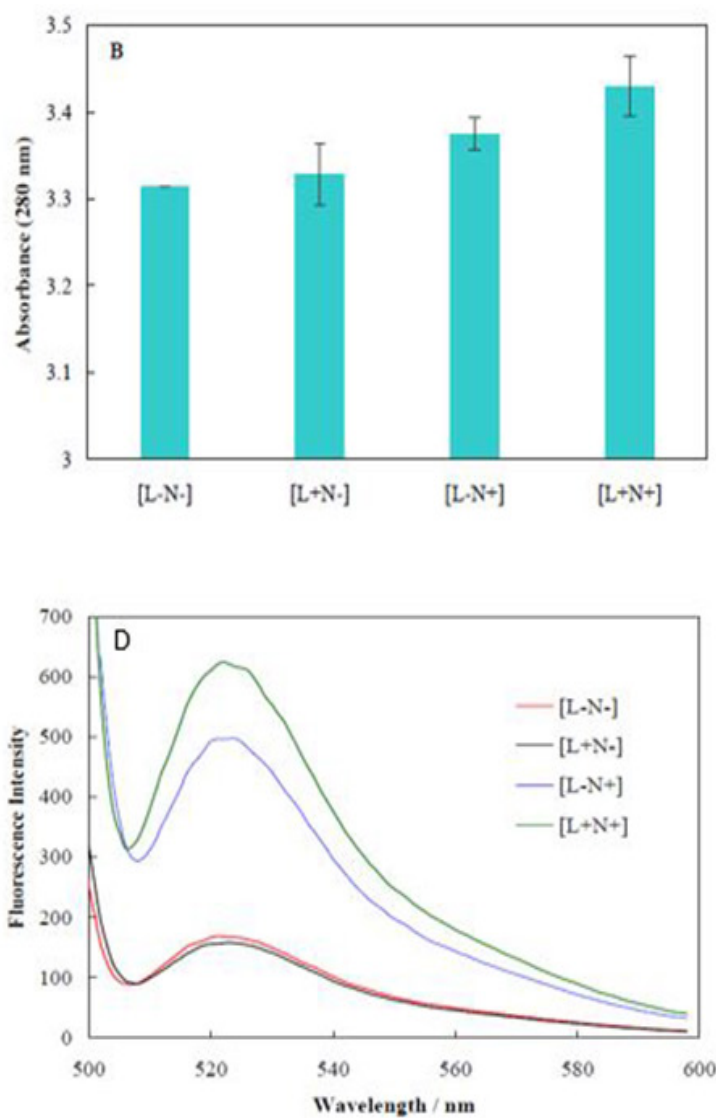

Figure 3: Absorption intensities of intracellular media of $\left[\mathrm{L}^{-} \mathrm{N}^{-}\right],\left[\mathrm{L}^{+} \mathrm{N}-\right],\left[\mathrm{L}^{-} \mathrm{N}^{+}\right]$and $\left[\mathrm{L}^{+} \mathrm{N}^{+}\right]$groups at different wavelengths of 595 (A), 280 (B) and $260 \mathrm{~nm}$ (C). And fluorescence spectra of [ $\mathrm{L}^{-} \mathrm{N}^{-}$], $\left[\mathrm{L}^{+} \mathrm{N}\right],\left[\mathrm{L}^{-} \mathrm{N}^{+}\right]$and $\left[\mathrm{L}^{+} \mathrm{N}^{+}\right]$groups of $250 \mu \mathrm{g} \mathrm{mL} \mathrm{L}^{-1} \mathrm{C}-\mathrm{PPy}$ and $1.0 \mathrm{~W} \mathrm{~cm}$ laser irradiation after interaction with DCFH (D). 
groups of $250 \mu \mathrm{g} \mathrm{mL}^{-1} \mathrm{C}$-PPy and $1.0 \mathrm{~W} \mathrm{~cm}^{-2}$ laser irradiation after interaction with $\mathrm{DCFH}$. The results pointed out that the fluorescence intensities for $\left[\mathrm{L}^{+} \mathrm{N}^{-}\right]$and $\left[\mathrm{L}^{-} \mathrm{N}^{-}\right]$groups were similar. Hence, laser irradiation could not stimulate formation of ROS. However, in the groups of $\left[\mathrm{L}^{-} \mathrm{N}^{+}\right]$and $\left[\mathrm{L}^{+} \mathrm{N}^{+}\right]$, ROS formation occurred. These results showed that although C-PPy exclusively produced ROS, laser irradiation led to enhancement in ROS generation. Therefore, C-PPy acts via both PTT and PDT mechanisms for killing the bacteria.

FESEM images of bacteria were recorded to investigate probable bactericidal laser ablation of C-PPy. Figures 4A and 4B show FESEM images of native and PTT treated PA at two magnifications. Untreated PA appeared in rod shapes. The images recorded from the treated
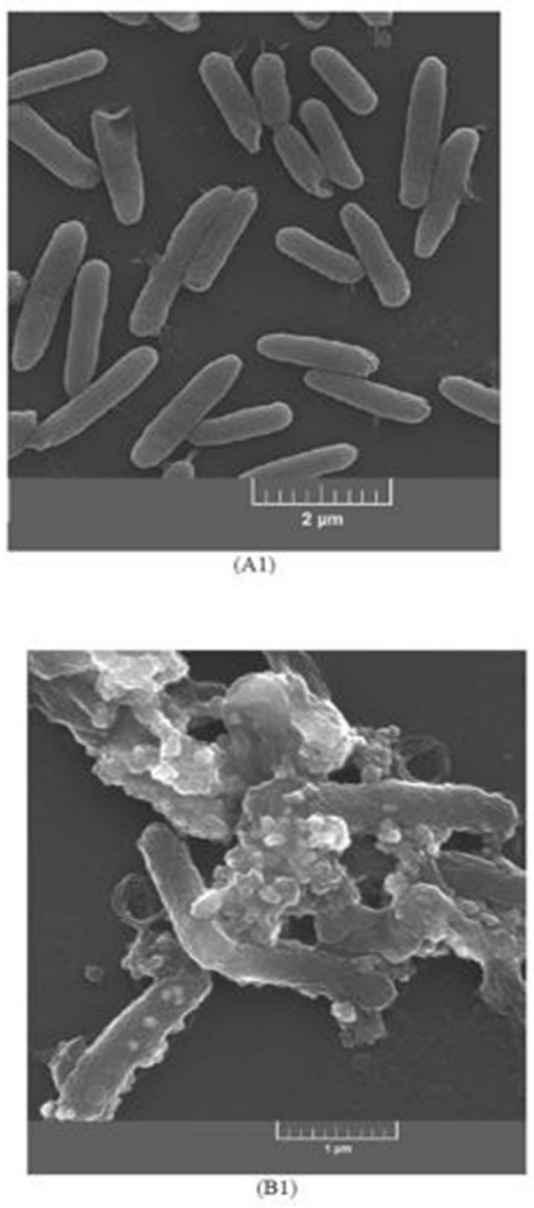

PA show that while C-PPy was fully attached to the PA surface, morphology and shape of the PA cells (treated with $250 \mu \mathrm{g} \mathrm{mL}^{-1} \mathrm{C}$-PPy and $1.0 \mathrm{~W} \mathrm{~cm}^{-2}$ laser irradiation) did not tremendously change with no vital alteration in the morphology or deformation in the cell surface.

\section{Discussion}

FESEM images helped us to figure out the size and morphology of C-PPy. At higher magnifications, the images indicate that the particles were adhered to very smaller particles. C-PPy is a nanocomposite of C-dots and PPy and composed of adhered C-dots by a network of PPy.

Temperature increment by PPy nanoparticles was higher than $\mathrm{C}$-dots, and both of them were
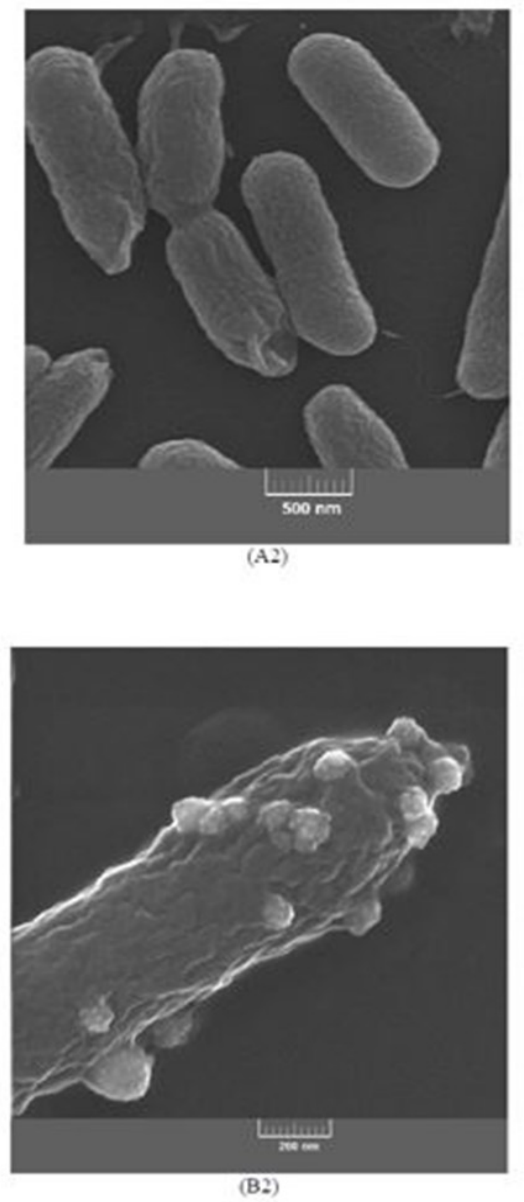

Figure 4: FESEM images at two magnifications of native $(A 1, A 2)$ and PTT treated PA $(B 1, B 2)$. 
lower than C-PPy. A recent study has proven that PPy nanoparticles in a core-shell structure with gold nanorods greatly improved the temperature elevation and photostability of the nanorods, compared to the bare gold nanorods [42]. Upon irradiation of this core-shell structure, PPy was polarized providing additional oscillating electrons accompanied by decrement in the electron vibrational space. These later effects led to a bathochromic shift in the absorption maximum of the core-shell structure to NIR region due to the Mie theory [42].

Statistical analysis of the presented values of survival or bactericidal rates indicated that treatment with different C-PPy concentrations affected the bacterial survival $(\mathrm{p}<0.05)$. Therefore, C-PPy had a function as a PTT agent to prevent bacteria growth by temperature elevation.

Cell's outer membrane plays a crucial role as a functional barrier and its damage might lead to leakage of cellular contents. Bacterial membrane integrity or disruption cell surface can be estimated by measuring the protein and DNA leakages [38]. The obtained results can be interpreted in terms of bigger size of DNA (compared to proteins) that can be released to the medium; it needs deeper damage in the membrane. It can be deduced that PTT did not inclusively damage the membrane integrity by C-PPy.

It has been reported that some nanomaterials have elevated ROS generation under laser irradiation along with heat productison. Therefore, these nanomaterials act via both the mechanisms of PTT and PDT for killing bacteria $[43,44]$. ROS induce damage in cells via oxidation of DNA, lipids and proteins. Generally, ROS are produced from irradiation to organic photosensitizers, but sometimes inorganic nanostructures, including quantum dots, $\mathrm{TiO}_{2}$, fullerenes and carbon nanotubes generate ROS upon irradiation $[45,46]$. Laser irradiation of noble metal nanomaterials induces confined resonance condition that redound singlet oxygen, superoxide radical anions or hydroxyl radicals [47]. A study showed that changing the wavelength of NIR irradiation into gold nonorods led to conversion of PTT to PDT behavior of the nanorods [48].

Attachment of C-PPy to the cell surface of bacteria is related to the lipophilic characters of polypyrrole which leads to locating this nanomaterial in cell membrane of bacteria consisting of lipid layers. Therefore, it seems that an important damage site of PA PTCC 1430, through ROS producing by PTT, occurs in the cytoplasmic membrane, or it inactivates enzymes and membrane transport systems. The reaction of these important cellular components may result in bacterial cell death [49].

\section{Conclusion}

Since the antibiotic resistance of bacterial strains, among different classes of gramnegative and gram-positive bacteria, has been increasing, it is needed to explore alternative antimicrobial treatment such as antimicrobial PTT. PTT combines non-toxic compound and light of appropriate wavelength without going on antibiotic complexity. The main reasons behind the bactericide effect of C-PPy as a nanomaterial are property of light capturing, raising the solution temperature and induction of ROS formation. Combination of C-dots with PPy provided both the advantage of NIR light absorbing (followed by heat producing) and ROS generating. Laser light irradiation on the attached C-PPy to the PA surface might change the membrane permeability. Alternatively, ROS reacted with many cellular components such as enzymes, proteins and lipids in bacterial cell leading ultimately to cell death. Photo-ablation strategy is a new minimal-invasive and inexpensive method without any overdose risk manner for combat with bacteria. PTT can be applied for rapid topical treatment besides routine antibacterial drugs.

\section{Acknowledgment}

This paper has been extracted from N. Behzadpour M.Sc. thesis supported by the Re- 
search Council of Shiraz University of Medical Sciences (14202).

\section{Conflict of Interest}

\section{None}

\section{References}

1. Blair JM, Webber MA, Baylay AJ, Ogbolu DO, Piddock LJ. Molecular mechanisms of antibiotic resistance. Nat Rev Microbiol. 2015;13:42-51. doi: 10.1038/nrmicro3380. PubMed PMID: 25435309.

2. Jia R, Yang D, Xu D, Gu T. Anaerobic Corrosion of 304 Stainless Steel Caused by the Pseudomonas aeruginosa Biofilm. Front Microbiol. 2017;8:2335. doi: 10.3389/fmicb.2017.02335. PubMed PMID: 29230206; PubMed PMCID: PMC5712129.

3. Magiorakos AP, Srinivasan A, Carey RB, Carmeli $Y$, Falagas ME, Giske CG, et al. Multidrug-resistant, extensively drug-resistant and pandrug-resistant bacteria: an international expert proposal for interim standard definitions for acquired resistance. Clin Microbiol Infect. 2012;18:268-81. doi: 10.1111/j.1469-0691.2011.03570.x. PubMed PMID: 21793988.

4. Strateva T, Yordanov D. Pseudomonas aeruginosa - a phenomenon of bacterial resistance. $J$ Med Microbiol. 2009;58:1133-48. doi: 10.1099/ jmm.0.009142-0. PubMed PMID: 19528173.

5. Breidenstein EB, De la Fuente-Nunez C, Hancock RE. Pseudomonas aeruginosa: all roads lead to resistance. Trends Microbiol. 2011;19:419-26. doi: 10.1016/j.tim.2011.04.005. PubMed PMID: 21664819.

6. Henderson TA, Morries LD. Near-infrared photonic energy penetration: can infrared phototherapy effectively reach the human brain? Neuropsychiatr Dis Treat. 2015;11:2191-208. doi: 10.2147/NDT. S78182. PubMed PMID: 26346298; PubMed PMCID: PMC4552256.

7. Ferreyra DD, Reynoso E, Cordero P, Spesia MB, Alvarez MG, Milanesio ME, et al. Synthesis and properties of 5,10,15,20-tetrakis[4-(3-N,N-dimethylaminopropoxy)phenyl] chlorin as potential broad-spectrum antimicrobial photosensitizers. J Photochem Photobiol B. 2016;158:243-51. doi: 10.1016/j.jphotobiol.2016.02.021. PubMed PMID: 26994333.

8. Negahdary M, Heli H. Applications of Nanoflowers in Biomedicine. Recent Pat Nanotechnol. 2018;12:22-33. doi: 10.2174/1872210511666170 911153428. PubMed PMID: 28901846.

9. Khatami M, Alijani HQ, Heli H, Sharifi I. Rectangular shaped zinc oxide nanoparticles: Green synthesis by Stevia and its biomedical efficiency. Ceramics International. 2018;44:15596-602. doi: 10.1016/j. ceramint.2018.05.224.

10. Khatami M, Mortazavi SM, Kishani-Farahani Z, Amini A, Amini E, Heli $\mathrm{H}$. Biosynthesis of Silver Nanoparticles Using Pine Pollen and Evaluation of the Antifungal Efficiency. Iran J Biotechnol. 2017;15:95-101. doi: 10.15171/ijb.1436. PubMed PMID: 29845056; PubMed PMCID: PMC5811059.

11. Bruchez Jr M, Moronne M, Gin P, Weiss S, Alivisatos AP. Semiconductor nanocrystals as fluorescent biological labels. Science. 1998;281:2013-6. PubMed PMID: 9748157.

12. Thanou M. Nanoparticles for Drug and Gene Delivery. In: Roberts G.C.K. (eds) Encyclopedia of Biophysics. Berlin, Heidelberg: Springer; 2013:168691. doi: 10.1007/978-3-642-16712-6_709.

13. Heli H, Rahi A. Synthesis and Applications of Nanoflowers. Recent Pat Nanotechnol. 2016;10:86-115. PubMed PMID: 27502388.

14. Nazari-Vanani R, Azarpira N, Heli H. Development of self-nanoemulsifying drug delivery systems for oil extracts of Citrus aurantium L. blossoms and Rose damascena and evaluation of anticancer properties. Journal of Drug Delivery Science and Technology. 2018;47:330-6. doi: 10.1016/j. jddst.2018.08.003.

15. Nazari-Vanani $R$, Sattarahmady $N$, Yadegari $H$, Heli $H$. A novel and ultrasensitive electrochemical DNA biosensor based on an ice crystals-like gold nanostructure for the detection of Enterococcus faecalis gene sequence. Colloids Surf $B$ Biointerfaces. 2018;166:245-53. doi: 10.1016/j. colsurfb.2018.03.025. PubMed PMID: 29602079.

16. Rahi A, Sattarahmady N, Heli H. An ultrasensitive electrochemical genosensor for Brucella based on palladium nanoparticles. Anal Biochem. 2016;510:11-7. doi: 10.1016/j.ab.2016.07.012. PubMed PMID: 27423961.

17. Ajdari M, Tondro G, Sattarahmady N, Parsa A, Heli $H$. Phytosynthesis of Silver Nanoparticles Using Myrtus communis L. Leaf Extract and Investigation of Bactericidal Activity. Journal of Electronic Materials. 2017;46:6930-5. doi: 10.1007/s11664017-5784-2.

18. Khatami M, Heli H, Jahani PM, Azizi H, Nobre MAL. Copper/copper oxide nanoparticles synthesis using Stachys lavandulifolia and its antibacterial activity. let Nanobiotechnology. 2017;11:709-13. doi: 10.1049/iet-nbt.2016.0189.

19. Khatami M, Alijani $H Q$, Heli $H$, Sharifi I. Rectangular shaped zinc oxide nanoparticles: Green synthesis 
by Stevia and its biomedical efficiency. Ceramics International. 2018;44:15596-602. doi: 10.1016/j. ceramint.2018.05.224.

20. Negahdary M, Behjati-Ardakani M, Sattarahmady $\mathrm{N}$, Yadegari H, Heli H. Electrochemical aptasensing of human cardiac troponin I based on an array of gold nanodumbbells-Applied to early detection of myocardial infarction. Sensors and Actuators B: Chemical. 2017;252:62-71. doi: 10.1016/j. snb.2017.05.149.

21. Negahdary M, Behjati-Ardakani M, Sattarahmady N, Heli H. An Aptamer-based Biosensor for Troponin I Detection in Diagnosis of Myocardial Infarction. J Biomed Phys Eng. 2018;8:167-78. PubMed PMID: 29951443; PubMed PMCID: PMC6015642.

22. Heli H. A study of double stranded DNA adsorption on aluminum surface by means of electrochemical impedance spectroscopy. Colloids Surf B Biointerfaces. 2014;116:526-30. doi: 10.1016/j. colsurfb.2014.01.046. PubMed PMID: 24576822.

23. Mahtab R, Rogers JP, Murphy CJ. Protein-sized quantum dot luminescence can distinguish between" straight"," bent", and" kinked" oligonucleotides. J Am Chem Soc. 1995;117:9099-100. doi: 10.1021/ja00140a040.

24. Harrison BS, Atala A. Carbon nanotube applications for tissue engineering. Biomaterials. 2007;28:34453. doi: 10.1016/j.biomaterials.2006.07.044.

25. Heidari M, Sattarahmady N, Javadpour S, Azarpira $\mathrm{N}$, Heli H, Mehdizadeh A, et al. Effect of Magnetic Fluid Hyperthermia on Implanted Melanoma in Mouse Models. Iran J Med Sci. 2016;41:31421. PubMed PMID: 27365553; PubMed PMCID: PMC4912650.

26. Molday RS, Molday LL. Separation of cells labeled with immunospecific iron dextran microspheres using high gradient magnetic chromatography. FEBS Lett. 1984;170:232-8. PubMed PMID: 6373372.

27. Sattarahmady N, Heidari M, Zare T, Lotfi M, Heli H. Zinc-Nickel Ferrite Nanoparticles as a Contrast Agent in Magnetic Resonance Imaging. $A p$ plied Magnetic Resonance. 2016;47:925-35. doi: 10.1007/s00723-016-0801-9.

28. Mody VV, Siwale R, Singh A, Mody HR. Introduction to metallic nanoparticles. J Pharm Bioallied Sci. 2010;2:282-9. doi: 10.4103/09757406.72127. PubMed PMID: 21180459; PubMed PMCID: PMC2996072.

29. Sattarahmady N, Rezaie-Yazdi M, Tondro GH, Akbari N. Bactericidal laser ablation of carbon dots: An in vitro study on wild-type and antibiotic-resistant Staphylococcus aureus. J Photochem Photobiol B. 2017;166:323-32. doi: 10.1016/j.jphoto- biol.2016.12.006. PubMed PMID: 28024283.

30. Singh R, Torti SV. Carbon nanotubes in hyperthermia therapy. Adv Drug Deliv Rev. 2013;65:204560. doi: 10.1016/j.addr.2013.08.001. PubMed PMID: 23933617; PubMed PMCID: PMC3914717.

31. Juzenas P, Chen W, Sun YP, Coelho MA, Generalov R, Generalova N, et al. Quantum dots and nanoparticles for photodynamic and radiation therapies of cancer. Adv Drug Deliv Rev. 2008;60:160014. doi: 10.1016/j.addr.2008.08.004. PubMed PMID: 18840487; PubMed PMCID: PMC2695009.

32. Jang J, Yoon H. Multigram-scale fabrication of monodisperse conducting polymer and magnetic carbon nanoparticles. Small. 2005;1:11959. doi: 10.1002/smll.200500237. PubMed PMID: 17193418.

33. Vardharajula S, Ali SZ, Tiwari PM, Eroglu E, Vig $\mathrm{K}$, Dennis VA, et al. Functionalized carbon nanotubes: biomedical applications. Int J Nanomedicine. 2012;7:5361-74. doi: 10.2147/IJN.S35832. PubMed PMID: 23091380; PubMed PMCID: PMC3471599.

34. Kagan VE, Konduru NV, Feng W, Allen BL, Conroy J, Volkov Y, et al. Carbon nanotubes degraded by neutrophil myeloperoxidase induce less pulmonary inflammation. Nat Nanotechnol. 2010;5:3549. doi: 10.1038/nnano.2010.44. PubMed PMID: 20364135.

35. Akasaka T, Matsuoka M, Hashimoto T, Abe S, Uo M, Watari F. The bactericidal effect of carbon nanotube/agar composites irradiated with nearinfrared light on Streptococcus mutans. Materials Science and Engineering: B. 2010;173:187-90. doi: 10.1016/j.mseb.2010.01.001.

36. Au KM, Lu Z, Matcher SJ, Armes SP. Polypyrrole nanoparticles: a potential optical coherence tomography contrast agent for cancer imaging. Adv Mater. 2011;23:5792-5. doi: 10.1002/ adma.201103190. PubMed PMID: 22102372.

37. Yang K, Xu H, Cheng L, Sun C, Wang J, Liu Z. In vitro and in vivo near-infrared photothermal therapy of cancer using polypyrrole organic nanoparticles. Adv Mater. 2012;24:5586-92. doi: 10.1002/ adma.201202625. PubMed PMID: 22907876.

38. Perez JM, Calderon IL, Arenas FA, Fuentes DE, Pradenas GA, Fuentes EL, et al. Bacterial toxicity of potassium tellurite: unveiling an ancient enigma. PLOS One. 2007;2:e211. doi: 10.1371/ journal.pone.0000211. PubMed PMID: 17299591; PubMed PMCID: PMC1784070.

39. Bradford MM. A rapid and sensitive method for the quantitation of microgram quantities of protein utilizing the principle of protein-dye binding. 
Anal Biochem. 1976;72:248-54. PubMed PMID: 942051.

40. Yousefi M, Dadashpour M, Hejazi M, Hasanzadeh M, Behnam B, De la Guardia M, et al. Anti-bacterial activity of graphene oxide as a new weapon nanomaterial to combat multidrug-resistance bacteria. Mater Sci Eng C Mater Biol Appl. 2017;74:568-81. doi: 10.1016/j.msec.2016.12.125. PubMed PMID: 28254332.

41. Domingue G, Costerton JW, Brown MR. Bacterial doubling time modulates the effects of opsonisation and available iron upon interactions between Staphylococcus aureus and human neutrophils. FEMS Immunol Med Microbiol. 1996;16:2238. doi: 10.1111/j.1574-695X.1996.tb00139.x. PubMed PMID: 9116639.

42. Du C, Wang A, Fei J, Zhao J, Li J. Polypyrrole-stabilized gold nanorods with enhanced photothermal effect towards two-photon photothermal therapy. Journal of Materials Chemistry B. 2015;3:4539-45. doi: 10.1039/C5TB00560D.

43. Gao L, Liu R, Gao F, Wang Y, Jiang X, Gao X. Plasmon-mediated generation of reactive oxygen species from near-infrared light excited gold nanocages for photodynamic therapy in vitro. ACS Nano. 2014;8:7260-71. doi: 10.1021/nn502325j. PubMed PMID: 24992260.

44. Huang X, Chen G, Pan J, Chen X, Huang N, Wang $X$, et al. Effective PDT/PTT dual-modal phototherapeutic killing of pathogenic bacteria by using ruthe- nium nanoparticles. Journal of Materials Chemistry B. 2016;4:6258-70. doi: 10.1039/C6TB01122E.

45. Samia AC, Chen X, Burda C. Semiconductor quantum dots for photodynamic therapy. J Am Chem Soc. 2003;125:15736-7. doi: 10.1021/ja0386905. PubMed PMID: 14677951.

46. Wang Y-W, Fu Y-Y, Wu L-J, Li J, Yang H-H, Chen G-N. Targeted photothermal ablation of pathogenic bacterium, Staphylococcus aureus, with nanoscale reduced graphene oxide. Journal of Materials Chemistry B. 2013;1:2496-501. doi: 10.1039/C3TB20144A.

47. Vankayala R, Kuo C-L, Sagadevan A, Chen P-H, Chiang C-S, Hwang KC. Morphology dependent photosensitization and formation of singlet oxygen $(1 \Delta \mathrm{g})$ by gold and silver nanoparticles and its application in cancer treatment. Journal of Materials Chemistry B. 2013;1:4379-87. doi: 10.1039/ C3TB2080.

48. Vankayala $R$, Huang $Y K$, Kalluru $P$, Chiang CS, Hwang KC. First demonstration of gold nanorodsmediated photodynamic therapeutic destruction of tumors via near infra-red light activation. Small. 2014;10:1612-22. doi: 10.1002/smll.201302719. PubMed PMID: 24339243.

49. Fu XJ, Fang Y, Yao M. Antimicrobial photodynamic therapy for methicillin-resistant Staphylococcus aureus infection. Biomed Res Int. 2013;2013:159157. doi: 10.1155/2013/159157. PubMed PMID: 23555074; PubMed PMCID: PMC3600246. 